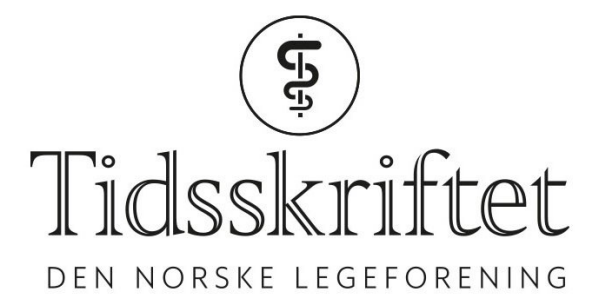

\title{
Skabb - et folkehelseproblem
}

LEDER

\section{EMILIA HUGDAHL}

E-post: emilia.signe.hugdahl@helse-bergen.no

Emilia Hugdahl er ph.d., spesialist i hud- og veneriske sykdommer på Bryggen Hudlegesenter og konstituert overlege ved Hudavdelingen, Haukeland universitetssjukehus. Forfatteren har fylt ut ICMJE-skjemaet og oppgir ingen interessekonflikter.

Forekomsten av skabb øker, og behandlingen er komplisert og dyr.

Mange fastleger og hudleger vil være enig i dette utsagnet: Skabb er blitt et folkehelseproblem. Skabb gir en intens og utbredt kløe som forstyrrer søvn og som over tid påvirker skoleprestasjoner, jobbevne og familieliv. Det er flaut og skambelagt, med sosial isolering som resultat. Tilstanden har potensielt stor negativ påvirkning på livskvalitet, og i tillegg kommer den $ø$ konomiske belastningen ved behandlingen. Mitt inntrykk er at helsemyndighetene bagatelliserer fremmarsjen av denne lille midden i befolkningen og konsekvensene den medfører.

Skabb er ikke definert som en seksuelt overførbar sykdom. Den kan smitte ved all form for direkte hudkontakt, men oftest ved intim kontakt. Tilstanden er ikke relatert til dårlig hygiene, og den forekommer i alle sosiale lag og aldre, både i småbarnsfamilier, i studentkollektiv og på sykehjem. Skabb er ikke meldepliktig, så det finnes ikke data på forekomsten. Vi har derimot tall på legekonsultasjoner der det er satt en skabbdiagnose, samt tall på solgte pakninger med permetrinkrem. Disse tallene ble publisert av Folkehelseinstituttet i 2019 og viser en formidabel $\emptyset$ kning i skabbforekomsten (1). I 2012 var det i Norge i underkant av 2 ooo konsultasjoner for skabb, i 2018 hadde dette tallet $\varnothing \mathrm{kt}$ til 6 ooo. Muntlige rapporter fra Folkehelseinstituttet, fastleger og hudleger gir ingen holdepunkt for at denne trenden har snudd, snarere tvert imot.

Parallelt med den økte forekomsten av skabb rapporteres det fra flere hold om behandlingssvikt. Dette gjelder ikke bare i Norge, men også globalt. Permetrinkrem og benzylbenzoatliniment er førstelinjebehandling (2). Mens det tidligere ofte var tilstrekkelig å ha på permetrinkrem i åtte timer, ser det nå ut til at kremen må være på i minimum 12-24 timer for å ha effekt. Skabbmiddens økte toleranse for permetrin gjenspeiles også i en betydelig $\emptyset$ kning i forskrivningen av ivermektintabletter, som brukes som andrelinjebehandling (3). Ved in vitro-studier med permetrin og ivermektin er det påvist nedsatt sensitivitet, men ingen resistens $(4,5)$. Etterspørselen etter permetrinkrem, benzylbenzoatliniment og ivermektintabletter er så stor at det stadig er tomt på apotekene pga. leveringsvansker (6).

Helsemyndighetene bagatelliserer fremmarsjen av denne lille midden i befolkningen og konsekvensene den medfører 
Behandlingen av skabb kan bli svært kostbar, og det finnes ingen refusjonsordninger. Permetrinkrem og benzylbenzoatliniment er reseptfrie preparater, og prisen varierer derfor fra apotek til apotek. En tube permetrinkrem (Nix) koster f.eks. 339 kroner på Apotek 1, mens Vitus apotek tar 475 kroner. En pakke ivermektintabletter (Scatol, 4 stk) koster 552 kroner. Verken for permetrinkrem eller benzylbenzoatliniment er det refusjon, og foreløpig er det heller ikke mulig å søke om individuell refusjon for ivermektin etter § 3 , men dette skyldes visstnok at preparatet er under metodevurdering hos Beslutningsforum.

La meg ta et fiktivt, men typisk eksempel fra vår hudpoliklinikk: En voksen mann trenger to tuber med permetrinkrem for adekvat påsmøring av hele kroppsoverflaten. Han trenger ytterligere to tuber, ettersom behandlingen skal gjentas etter en uke. I tillegg skal hans kone og tre barn behandles to ganger. Totalt må familiefaren kjøpe 12 tuber krem for å gjennomføre standard førstelinjebehandling av skabb. Han må da betale ca. 4 o68-5 70o kroner for hele familien. Så viser det seg at det er praktisk vanskelig å gjennomføre helkroppssmøringen adekvat, og saneringen blir bare delvis gjennomført. Etter denne behandlingssvikten må pasienten få ivermektintabletter. Han veier $90 \mathrm{~kg}$ og må ha tre pakker, til 1656 kroner. I mellomtiden blir besteforeldrene, som har vært barnevakt for barna, smittet, som så igjen resmitter yngstesønnen. Familien må nå gjennom en ny behandlingsrunde, denne gangen med kombinasjonsbehandling av permetrinkrem og ivermektintabletter. Prisen er ca. 10 ooo kroner.

Jeg mistenker at den labre oppmerksomheten rundt skabb og manglende refusjonsordninger for behandling skyldes at skabb har lav status i sykdomshierarkiet

Dette er store utgifter for de fleste av oss. Noen har rett og slett ikke råd til behandlingen. Det kan være studenten i bokollektivet eller aleneforsørgeren uten fast jobb. At pasienter ikke gjennomfører skabbehandlingen fordi det er for kostbart, er svært uheldig og bidrar til en negativ smittespiral.

Helsemyndighetene har et særskilt ansvar for å forebygge og behandle smittsomme sykdommer. Jeg mistenker at den labre oppmerksomheten rundt skabb og manglende refusjonsordninger for behandling skyldes at skabb har lav status i sykdomshierarkiet. Selv om skabb ikke er farlig, er det en sykdom med stor negativ påvirkning på livskvalitet. Med det omfanget sykdommen nå har, må skabb kalles et folkehelseproblem. Våre helsemyndigheter bør vurdere følgende tiltak for å bekjempe problemet: informasjonskampanjer om skabb rettet mot både befolkningen og helsepersonell, sikre tilstrekkelige leveranser av permetrin, benzylbenzoat og ivermektin til apotekene samt etablere refusjonsordninger for å få billigere behandling for pasientene.

LITTERATUR:

1. Amato E, Dansie LS, Grøneng GM et al. Increase of scabies infestations, Norway, 2006 to 2018. Euro Surveill 2019; 24: 190020. [PubMed][CrossRef]

2. Folkehelseinstituttet. Skabb - veileder for helsepersonell.

https://www.fhi.no/nettpub/smittevernveilederen/sykdommer-a-a/skabb-veileder-for-helsepersonell/ Lest 5.10.2020.

3. Kråkenes C, Nordvåg HB. Eksplosjon i salg av reseptbelagt skabbmedisin:- Kan tyde på resistens. NRK Troms og

Finnmark.https://www.nrk.no/tromsogfinnmark/eksplosjon-i-salg-av-reseptbelagt-skabbmedisin_-_-k an-tyde-pa-resistens-1.14621448/ Lest 5.10.2020.

4. Pallesen K, Lassen JA, Munk NT et al. In vitro survival of scabies mites. Clin Exp Dermatol 2020; 45: 712-5. [PubMed][CrossRef]

5. Mounsey KE, Holt DC, McCarthy J et al. Scabies: molecular perspectives and therapeutic implications in the face of emerging drug resistance. Future Microbiol 2008; 3: 57-66.

[PubMed][CrossRef] 
6. Statens legemiddelverk. Legemiddelmangel - oversikt og råd. https://legemiddelverket.no/legemiddelmangel Lest 5.10.2020.

Publisert: 26. oktober 2020. Tidsskr Nor Legeforen. DOI: 10.4045/tidsskr.20.0799

(C) Tidsskrift for Den norske legeforening 2020. Lastet ned fra tidsskriftet.no 